\title{
Investigation of the Optimum Time for Intravenous Access After Anesthesia Induction with Sevoflurane in Pediatric Patients Without Premedication
}

\author{
Premedikasyon Uygulanmayan Pediyatrik Hastalarda Sevofluran ile \\ Anestezi İndüksiyonu Sonrası İntravenöz Girişim için Optimum Sürenin \\ Araştırılması
}

\section{Zeynep Nur ORHON $\odot$, Cem ORHON $\odot$}

Ethics Committee Approval: This study was approved by the Istanbul Medeniyet University Goztepe Training and Research Hospital, Clinical Studies Ethics Committee, 12 December 2018, 2018/0478. Conflict of interest: The authors declare that they have no conflict of interest. Funding: None.

Informed Consent: Informed consent was taken from the patients enrolled in this study.
Cite as: Orhon ZN, Orhon C. Investigation of the Optimum Time for Intravenous Access after Anesthesia Induction with Sevoflurane in Pediatric Patients without Premedication. Medeniyet Med J. 2020;35:85-90.

\begin{abstract}
Objective: Anesthesia induction is usually achieved with sevoflurane for pediatric patients without vascular access. The aim of this study was to investigate the optimum intravenous access time and to evaluate the corresponding bispectral index (BIS) value in pediatric patients after sevoflurane induction.

Method: This prospective study included 100 children enrolled between January 1, 2017 and January 1, 2018 at Istanbul Medeniyet University Goztepe Training and Research Hospital. Anesthesia was induced with $8 \%$ sevoflurane and oxygen. Measurements included mask adaptation time, time to loss of the ciliary reflex, time to recovery of regular breathing, and optimal timing of intravenous access time with the corresponding BIS values, as well as the time elapsed for the BIS value to fall below 60 .

Results: The mean mask adaptation time was $27.8 \pm 28.4 \mathrm{~s}$, time to loss of the ciliary reflex was $39.7 \pm 10.3 \mathrm{~s}$, and time to reach regular respiration was $88.5 \pm 116.9 \mathrm{~s}$, with mean BIS value of $80.4 \pm 16.9,70.2 \pm 10.4$, and $52.4 \pm 12.1$, respectively. The mean time for BIS to fall below 60 was $72.54 \pm 24.41 \mathrm{~s}$. The mean time required for the the iniation of optimal intravenous access was $104.92 \pm 36.45 \mathrm{~s}$, with a mean BIS value of $30 \pm 10.1$.

Conclusion: Following anesthesia induction with sevoflurane in children, the BIS value below 60 which is the upper limit for surgical anesthesia, was found to be insufficient for intravenous intervention. For pediatric patients undergoing sevoflurane induction it has been concluded that, the BIS value below 30 or an average waiting time of $104.9 \mathrm{~s}$ is ideal for initiation of optimal intravenous access.
\end{abstract}

Keywords: Intravenous access, sevoflurane, bispectral index, pediatric patient

öz

Amaç: Damar yolu olmayan pediyatrik hastalarda, anestezi indüksiyonu genelikle sevofluran ile yapılır. Amacımız, sevofluran indüksiyonundan sonra pediyatrik hastalarda optimum intravenöz girişim süresini ve bu süreye karşılık gelen bispektral indeks (BIS) değerini araştırmaktır.

Yöntem: Bu prospektif çalışmaya, 1 Ocak 2017 ile 1 Ocak 2018 tarihleri arasında Istanbul Medeniyet Üniversitesi Göztepe Eğitim ve Araștırma Hastanesine kayıtı 100 çocuk dahil edilmiştir. Anestezi indüksiyonu \% 8 sevofluran ve oksijen ile yapıldı. Ölçümler, maske uyum zamanı, siliyer refleksin kayıp süresi, düzenli solunuma ulaşma süresi ve bunlara karşılık gelen BIS değerleri ile optimal intravenöz girişim süresini ve BIS değerinin 60'ın altına düşmesi için geçen süreyi icermektedir.

Bulgular: Ortalama maske uyum süresi $27,8 \pm 28,4$ s, siliyer reflex kaybına kadar geçen süre $39,7 \pm 10,3 \mathrm{~s}$, düzenli solunuma ulaşma süresi $88,5 \pm 11,9 \mathrm{~s}$, ve bunlara karşllık gelen ortalama BIS değerleri sırasıyla $80,4 \pm 16,9,70,2 \pm 10,4$ ve $52,4 \pm 12,1$ idi. BIS'in 60'ın altına düsmesi icin ortalama süre $72,54 \pm 24,41$ s, optimal intravenöz girişim için gereken ortalama süre 104,92 $\pm 36,45$ $s$ ve bu sıradaki ortalama BIS değeri $30 \pm 1$. 1 idi.

Sonuc: Cocuklarda sevofluran ile anestezi indüksiyonunu takiben, cerrahi anestezi için üst sınır olan 60'ın altındaki BIS değerinin intravenöz müdahale için yetersiz olduğu görülmüştür. Sevofluran indüksiyonu uygulanan pediyatrik hastalarda optimal intravenöz girişim için 30'un altındaki BIS değerinin veya ortalama 104.9 s'lik bekleme süresinin ideal olduğu sonucuna varılmıştır.

Anahtar kelimeler: İntravenöz girişim, sevofluran, bispektral indeks, pediyatrik hasta
Received: 3 May 2020

Accepted: 30 May 2020

Online First: 30 June 2020

\section{Corresponding Author:}

Z.N. Orhon

ORCID: 0000-0003-3184-2393 Istanbul Medeniyet University, Faculty of Medicine, Goztepe Training and Research Hospital, Department of Anesthesiology and Reanimation, Istanbul, Turkey

zeynepnurorhon@gmail.com

\section{Orhon}

ORCID: 0000-0001-7949-4127 Private Yuzyll Hospital, Department of Neurosurgery, Istanbul, Turkey 


\section{INTRODUCTION}

At least one vascular access must have been opened for administration of intravenous drugs and fluids in patients undergoing anesthesia. Fear of needle to be inserted to provide vascular access may cause anxiety about feeling pain and discomfort in pediatric patients. For this reason, inhalation anesthetics are commonly used for anesthesia induction in children. A smooth and fast onset, little irritation to the respiratory tract, and lack of undesirable side effects are the characteristics of an ideal inhalational anesthetic agent ${ }^{1,2}$. Since it meets all these criteria, sevoflurane is widely used for anesthesia induction in pediatric patients.

Any monitoring method cannot yet determine the timing of intravenous cannulation after anesthesia induction. Pediatric anesthesiologists use their experience, as well as clinical parameters such as the ciliary reflex loss, regular respiration, heart rate and muscle tone to decide on the cannulation time.

Limited data are available in the literature regarding intravenous access time after anesthesia induction $^{3-5}$. There is only one study investigating the BIS value at optimum intravenous access time ${ }^{3}$. The primary aim of this study is to investigate the optimum intravenous access time in children undergoing anesthesia induction. The secondary aim is to evaluate the bispectral index (BIS) values and sevoflurane concentrations during the stages of anesthesia induction and intravenous access.

\section{MATERIAL and METHODS}

This prospective study was approved by the institutional ethical committee of Istanbul Medeniyet University Goztepe Training and Research Hospital, Clinical Researchers Ethics Committee (2014/0149), and informed consent forms were signed by the parents or the guardians for each child's participation in the study. The study was conducted according to the principles and re- quirements of the Declaration of Helsinki between 1st January 2017 and 1st January 2018 in Istanbul Medeniyet University Goztepe Training and Research Hospital. The study was registered to Clinical Trials.gov Protocol Registration and Results System on December 62019 with the registration number of NCT04190407.

One hundred pediatric patients with American Society of Anesthesiologists (ASA) physical status I or II; aged between 2 months to 11 years; and scheduled for the day of case surgery (including inguinoscrotal hernia or hydrocele, undescended testis, hypospadias, or routine circumcision) or diagnostic procedures (e.g., cystoscopy) or external ventricular drainage were included in the study. Patients with obesity, malnutrition, gastroesophageal reflux disease, allergy, or sensitivity to volatile anesthetics or those undergoing procedures lasting more than two hours were excluded from the study. Preanesthetic evaluation and routine investigations were carried out before surgery.

\section{Anesthesia}

Standard intraoperative monitoring consisting of electrocardiography (ECG), noninvasive blood pressure (BP) measurement, pulse oximetry $\left(\mathrm{SpO}_{2}\right)$, capnography, and gas analysis in the ventilator (Mindray WATO EX-65, Shenzhen Mindray Bio. Medical Electronics Co. Ltd. China) was used in all cases. Patients were also monitored by BIS (IPX2 Covidien, BIS LoC 4 Channel, USA). The skin for the sensor attachment area was cleaned with alcohol and then dried, and the BIS sensor (Aspect Medical Systems, Inc., USA) was attached afterwards. The patient's heart rate (HR), systolic blood pressure (SBP), diastolic blood pressure (DBP), as well as the inspired and end-tidal sevoflurane concentrations and $\mathrm{O}_{2}$ saturation, were recorded before, and at the end of induction, after starting the operation, and every 5 minutes during maintenance of anesthesia. The time elapsed from the beginning of the induction to the placement of the laryngeal mask was also recorded. 
Z.N. Orhon and C. Orhon, Investigation of the Optimum Time for Intravenous Access After Anesthesia Induction with Sevoflurane in Pediatric Patients Without Premedication

None of the patients were premedicated. The induction was performed with $8 \%$ sevoflurane and $100 \%$ oxygen by the tidal breath technique through a face mask. The fresh gas flow was adjusted to $6 \mathrm{~L} / \mathrm{min}^{-1}$. The breathing system was primed with $8 \%$ sevoflurane and $100 \%$ oxygen. A tourniquet was used to enhance venous filling every 15 seconds after the ciliary reflex disappeared. If the patient did not show any response to the tourniquet (movement, cough, or laryngospasm), an experienced anesthesiologist entered the vein, preferably on the back of one hand, using a 22-24 gauge cannula. The following data were recorded: face mask adaptation time, time to the loss of the ciliary reflex, the regular breathing time, and initiation of intravenous access (the time interval from the start of sevoflurane inhalation through the face mask to disappearrance of withdrawal response which allowed venous access), the corresponding BIS values, the inspired and expired sevoflurane concentrations at these time points, time to BIS decline under 60 , and the total induction time (the duration from the beginning of induction to the placement of the laryngeal mask). After successful intravenous access, $0.9 \% \mathrm{NaCl}$ solution was initiated according to the 4-2-1 rule and $1 \mu \mathrm{g} \mathrm{kg}^{-1}$ fentanyl was given. Spontaneous respiration was assisted. The tip of an appropriately sized standard laryngeal mask airway (LMA Classic TM) was lubricated with $2 \%$ lidocaine spray and placed with the standard insertion technique. It was secured and inflated according to the manufacturer's instructions, and the sevoflurane concentration was decreased to 3 percent.

\section{Statistical Analysis}

The sample size calculation was based on the Dixon's method, which requires at least six pairs of failed, and successful attempts 6. Data were expressed as mean \pm standard deviations for continuous or as percentages of the total for categorical variables. Partial correlation was used to test the relationship between the age and time to intravenous intervention.

\section{RESULTS}

In total, 100 patients were recruited. At the time of completion of the study, data from 16 patients were missing on the evaluation forms, so the final study population consisted of 84 patients. Table 1 shows the demographic data of the patients. No complications, such as excitatory movements, hiccups, laryngospasm, or coughing occurred related to the induction of anesthesia. Table 2 shows the anesthesia parameters used during the induction. The mean time to adaptation of the mask was $27.8 \pm 28.4 \mathrm{~s}$, the time to loss of ciliary reflex was $39.7 \pm 10.3 \mathrm{~s}$, and the time to reach regular respiration was $88.5 \pm 116.9 \mathrm{~s}$, while the corresponding mean BIS values were $80.4 \pm 16.9,70.2 \pm 10.4$, and

\section{Table 1. Demographic data.}

Gender (Female/Male)

ASA I/II

Age (Year)

Weight $(\mathrm{Kg})$

Mean anesthesia duration (Min)

Mean procedure duration (Min)

Mean time spent in the operating theater (Min)
$13 / 71(15.7 \%-84.3 \%)$

79/5 (93.9\%-6.1\%)

$4.49 \pm 2.39(0.2-11)$

$17.37 \pm 5.87(4.5-33)$

$30.1 \pm 13.9$

$25.4 \pm 12.7$

$36.7 \pm 16.6$

Table 1. Demographic data.

\begin{tabular}{|c|c|c|c|c|}
\hline Variables & Time (s) & BIS Value & $\begin{array}{l}\text { Inspired sevoflurane } \\
\text { concentration } \%\end{array}$ & $\begin{array}{l}\text { Expired sevoflurane } \\
\text { concentration } \%\end{array}$ \\
\hline Mean mask adaptation time & $27.8 \pm 28.4$ & $80.4 \pm 16.9$ & $5.25 \pm 3.27$ & $3.81 \pm 2.50$ \\
\hline Mean elapsed time to the loss of ciliary reflex & $39.7 \pm 10.3$ & $70.2 \pm 10.4$ & $7.1 \pm 0.9$ & $4.9 \pm 1.2$ \\
\hline Time to BIS under 60 & $72.5 \pm 24.4$ & & $7.4 \pm 0.8$ & $6.3 \pm 1.1$ \\
\hline Time to reach regular respiration & $88.5 \pm 116.9$ & $52.4 \pm 12.1$ & $7.6 \pm 1.1$ & $6.9 \pm 1.4$ \\
\hline Time to intravenous access & $104.92 \pm 36.4$ & $30 \pm 10.1$ & $8.0 \pm 1.1$ & $7.6 \pm 2.1$ \\
\hline Total induction time & $170.83 \pm 48$ & & & \\
\hline
\end{tabular}

BIS: Bispectral index, s: seconds 
$52.4 \pm 12.1$, respectively. The mean time for BIS to fall below 60 was $72.54 \pm 24.41 \mathrm{~s}$. The mean time required to start intravenous access was $104.92 \pm 36.45 \mathrm{~s}$, and the corresponding mean BIS value was $30 \pm 10.1$ at that time point. The total induction time was $170.83 \pm 48 \mathrm{~s}$. After adjusted for gender, there was a weakly positive, and statistically insignificant correlation between age and the time of intravenous intervention $(r=0.207$, $\mathrm{p}=0.062$ ).

\section{DISCUSSION}

Anesthesia induction is more challenging in children than adults. Obtaining a proper intravenous access can be troublesome; therefore, induction of inhalation anesthesia is the preferred technique in the pediatric age group. Sevoflurane has a pleasant odor and is non-irritating to the airways, which makes its use ideal for children ${ }^{1}$. However, the clinical indicators of sevoflurane induction and their correlation with BIS values have not yet been investigated in the literature.

One previous study compared the induction characteristics of sevoflurane and halothane anesthesia on children ${ }^{7}$. Sevoflurane was initially set at $1 \%$ and then increased stepwise by $1 \%$ every 3-4 breaths to a maximum of $6 \%$, until the eyelash reflex was lost. The time to loss of the eyelash reflex was $69.26 \pm 27.85 \mathrm{~s}$, which was longer than in our study. This difference can be attributed to the gradual increase in sevoflurane concentration in that study. Sigston et al. ${ }^{8}$ used $8 \%$ sevoflurane, as in our study, and stated that a high sevoflurane concentration provides a faster induction. These two studies did not analyze either BIS values or intravenous access times.

Tomal et al. ${ }^{9}$ divided their patients into two groups and used two brands of sevoflurane for anesthesia induction, supplied at $2.5 \%$. The median time to reach regular breathing was similar in both groups as 189 s vs $184 \mathrm{~s}$; the time to loss of the ciliary reflex was 52 s vs 50 s, and the total induction time was 240 s vs $246 \mathrm{~s}$. All these values were higher than the ones obtained in our study. This probably reflects the higher sevoflurane concentration used in the present study. Although we used sevoflurane at $8 \%$ concentration in anesthesia induction, we did not encounter any side effect. The hemodynamic parameters at several time points were comparable in both studies. No BIS values were provided by Tomal et al. ${ }^{9}$ in their article.

The depth of anesthesia is typically assessed in current clinical practice using BIS monitors based on the electroencephalography (EEG) principles. BIS monitoring is helpful in preventing anesthesia complications and in reducing costs by avoiding excessive anesthesia. It can also prevent persistence of awareness during light anesthesia ${ }^{10-12}$.

BIS monitoring has been used in pediatric patients for a long time. There are lots of studies about the use and reliability of BIS monitoring in pediatric patients. McCann et al. ${ }^{13}$ reported that end-tidal sevoflurane concentrations were closely correlated with BIS in preschool children undergoing sevoflurane anesthesia for tonsillectomy and adenoidectomy. Whyte et al. ${ }^{14}$ recruited 33 pediatric patients who would undergo elective cardiac catheterization under isoflurane anesthesia. They found that the relationship between BIS and isoflurane concentration used was similar to that seen in adults receiving isoflurane and in children receiving sevoflurane. They reported that BIS monitoring may be used in pediatric patients older than one year and may be useful as a monitor of anesthetic depth ${ }^{14}$. Murat et al. ${ }^{15}$ stated that the BIS monitor is absolutely a useful tool for children to avoid light anesthesia causing awareness or to avoid very deep anesthesia leading to undesirable cardiovascular effects or brain damages.

We found that sevoflurane at $8 \%$ concentration reduced the BIS value to below 60 in approximately 72 s during induction. A BIS value between 40 and 60 is considered as "deep surgical anesthesia" 16 . Mychaskiw et al. ${ }^{17}$ reported an intraoperative 
Z.N. Orhon and C. Orhon, Investigation of the Optimum Time for Intravenous Access After Anesthesia Induction with Sevoflurane in Pediatric Patients Without Premedication

awareness under sevoflurane-N2O anesthesia with a BIS value of 47 in adults and concluded that a BIS value around 50 is inadequate for preventing an explicit recall or an awareness reaction during anesthesia. They did not evaluate the parameters at induction. The patients in the present series reacted with hand movements and agitation during attempts at intravenous line insertion even after their mean BIS values were below 60 during induction. A smooth intravenous access with losing awareness could be achieved only after the mean BIS value dropped below 30 and at the $104.9^{\text {th }}$ second of anesthesia induction. This is a remarkable finding because it is well below the mean BIS value considered to be indicative of deep surgical anesthesia. The mean inspired, and expired sevoflurane concentrations were respectively $8.0 \pm 1.1 \%$ and $7.6 \pm 2.1 \%$ during successful intravenous access.

Early intravenous access during inhalation induction may result in movement, breath holding, coughing, and even laryngospasm. Delayed intravenous access is also dangerous for safety of anesthesia induction $^{5}$. For these reasons, the timing of intravenous access is of great importance.

Some studies have aimed to determine the timing of intravenous intervention. For example, Joshi et al. ${ }^{18}$ used the Dixon's up-and-down staircase method in children aged from 4 to 10 years. The children were not premedicated, and general anesthesia was induced with $8 \%$ sevoflurane and oxygen with a mask. After the loss of the ciliary reflex, sevoflurane concentration was reduced to $5 \%$, the fresh gas flow to $3 \mathrm{~L}$, and the timer was started. They found that the time to optimal intravenous cannulation in $50 \%$ and $95 \%$ of patients were $1.90 \mathrm{~min}$ and $3.32 \mathrm{~min}$ respectively. They recommended that the optimal time interval was 3.5 min for attempting intravenous cannulation after the loss of ciliary reflex. Similarly, Schwartz et al. ${ }^{5}$ used $8 \%$ sevoflurane with $66 \%$ nitrous oxide in oxygen. When the child's eyes closed and the ciliary reflex had disappeared, nitrous oxide was discontinued and the timer was started. For the majority of children, they found that the best protocol was to wait for 2 min prior to attempting intravenous access.

Kilicaslan et al. ${ }^{3}$ also used 8\% sevoflurane and nitrous oxide-oxygen (50:50) with a high fresh gas flow (6 $\mathrm{Lmin}^{-1}$ ) after midazolam premedication. After loss of the ciliary reflex, fresh gas flow was reduced to $3 \mathrm{Lmin}^{-1}$, sevoflurane concentration to $5 \%$, and the timer was started. They found that the optimum time to cannulation in 2-6 years old unresponsive children was 2 min and the mean BIS value was $37.5^{3}$. Despite the use of midazolam premedication and the addition of nitrous oxide to sevoflurane for induction in that study, the mean time to intravenous access was longer and the mean BIS value was higher than our study. We think that the longer duration and the higher BIS value are due to the decreased sevoflurane concentration after the loss of the eyelash reflex. In our study, sevoflurane concentration was decreased after accessing the vein. However, the BIS value obtained by Kılıçaslan et al. ${ }^{3}$ for the optimal intravenous access was well below 60 , which is considered as an upper limit for surgery. In this respect their BIS value was compatible with our result.

Hasan et al. studied the optimum time for intravenous cannulation after induction with sevoflurane, oxygen, and nitrous oxide in children aged 2-6 years undergoing elective dental surgery without application of any premedication ${ }^{4}$. Although their work differs from the present study in terms of nitrogen oxide use, similar to our study results (104.9 s), a 105 seconds of waiting time was recommended by the authors for the start of optimal intravenous access. Since the authors did not use the BIS monitor in their work, there is no BIS value to compare with our BIS result. Kumar et al. ${ }^{19}$ used $8 \%$ sevoflurane and oxygen via a mask and found that the mean time to intravenous access in children aged 1-3 years was significantly shorter (54 s) when compared with children older than 3 
years (105 s and $144 \mathrm{~s}$ ). After adjusted for gender, there was a weakly positive, but statistically insignificant correlation between age and the time to initiation of intravenous intervention in our study. The given value was the average time estimated for patients aged between 2 months and 11 years.

\section{CONCLUSION}

This clinical trial revealed that anesthesia induction with sevoflurane reduced the BIS value below 60 within approximately 72 s. Following sevoflurane induction in children, a BIS value below 60 , which is the upper limit for surgical anesthesia, was found insufficient for the initiation of intravenous intervention. It was concluded that a BIS value less than 30 or a mean waiting time of 104.9 $s$ is ideal for the optimum intravenous access in pediatric patients after sevoflurane induction.

\section{REFERENCES}

1. Lerman J, Davis PJ, Welborn LG, et al. Induction, recovery, and safety characteristics of sevoflurane in children undergoing ambulatory surgery. Anesthesiology 1996;84:1332-40. [CrossRef]

2. Nathanson MH, Fredman B, Smith I, White PF. Sevoflurane versus desflurane for outpatient anesthesia: a comparison of maintenance and recovery profiles. Anesth Analg 1995;8:1186-90. [CrossRef]

3. Kilicaslan A, Gök F, Erol A, Okesli S, Sarkilar G, Otelcioglu S. Determination of optimum time for intravenous cannulation after induction with sevoflurane and nitrous oxide in children premedicated with midazolam. Paediatr Anaesth 2014;24:620-4. [CrossRef]

4. Hasan AK, Sivasankar R, Nair SG, Hasan WU, Latif Z. Optimum time for intravenous cannulation after induction with sevoflurane, oxygen, and nitrous oxide in children without any premedication. Paediatr Anaesth. 2018;28:179-83. [CrossRef]

5. Schwartz D, Connelly NR, Gutta S, Freeman K, Gibson C.
Early intravenous cannulation in children during sevoflurane induction. Paediatr Anaesth 2004;14:820 4. [CrossRef]

6. Dixon WJ. Staircase bioassay: the up-and-down method. Neurosci Biobehav Rev 1991;15:47-50. [CrossRef]

7. Dedhia KN, Kudalkar A. Comparison of sevoflurane and halothane for induction of anaesthesia and laryngeal mask airway insertion in paediatric patients. Indian J Anaesth 2004; 48:465-8.

8. Sigston PE, Jenkins AMC, Jackson EA, Sury MRJ, Mackersie $A M$, Hatch DJ. Rapid inhalation induction in children: $8 \%$ sevoflurane compared with $5 \%$ halothane. Br J Anaesth 1997;78:362-5. [CrossRef]

9. Tomal CRG, Silva AGPD, Yamashita AM, et al. Assessment of induction, recovery, agitation upon awakening, and consumption with the use of two brands of sevoflurane for ambulatory anesthesia. Rev Bras Anestesiol 2012;62:154-72. [CrossRef]

10. Musizza B, Ribaric S. Monitoring the depth of anaesthesia. Sensors (Basel) 2010;10:10896-10935. [CrossRef]

11. Avidan MS, Zhang L, Burnside BA, et al. Anesthesia awareness and the bispectral index. $\mathrm{N}$ Engl J Med 2008;358:1097-108. [CrossRef]

12. Dahaba AA. Different conditions that could result in the bispectral index indicating an incorrect hypnotic state. Anesth Analg 2005;101:765-73. [CrossRef]

13. McCann ME, Bacsik J, Davidson A, Auble S, Sullivan L, Laussen. The correlation of bispectral index with endtidal sevoflurane concentration and haemodynamic parameters in preschoolers. Paediatr Anaesth 2002;12:519-25. [CrossRef]

14. Whyte SD, Booker PD. Bispectral index during isoflurane anesthesia in pediatric patients. Anesth Analg 2004;98:1644-9. [CrossRef]

15. Murat I, Constant I. Editorial Bispectral index in pediatrics: fashionor a newtool? Paediatr Anaesth 2005;15:177-80. [CrossRef]

16. Hajat Z, Ahmad N, Andrzejowski J. The role and limitations of EEG-based depth of anaesthesia monitoring in theatres and intensive care. Anaesthesia 2017;72 (Suppl.1):38-47. [CrossRef]

17. Mychaskiw G II, Horowitz M, Sachdev V, Heath BJ. Explicit intraoperative recall at a bispectral index of 47 . Anesth Analg 2001;92:808-9. [CrossRef]

18. Joshi A, Lee S, Pawar D. An optimum time for intravenous cannulation after induction with sevoflurane in children. Paediatr Anaesth 2012;22:445-8. [CrossRef]

19. Kumar KR, Sinha R, Chandiran R, Pandey RK, Darlong V, Chandralekha $C$. Evaluation of optimum time for intravenous cannulation after sevoflurane induction of anesthesia in different pediatric age groups. J Anesthesiol Clin Pharmacol 2017;33:371-4. [CrossRef] 